\title{
STUDENTS' METACOGNITIVE AWARENESS AND READING COMPREHENSION OF NARRATIVE TEXTS
}

\author{
Rosnaeni, Muhammad Zuhri Dj. *, Hasriati Nur \\ Institut Agama Islam Negeri Bone, Indonesia \\ (zuhristaindije@gmail.com)
}

Received: $20^{\text {th }}$ March 2020; Revised: $17^{\text {th }}$ May 2020; Accepted: $28^{\text {th }}$ June 2020

\begin{abstract}
This study aims to describe the relationship of students' metacognitive awareness and their reading comprehension of narrative texts by employing a correlational study design. The participants of this study were students of IPS 3 Class of SMAN 3 Bone, South Sulawesi, consisting of 25 students. They were selected as participants for this study using cluster sampling. The researchers used a questionnaire and test to collect the data from participants. The questionnaire was used to determine the students' metacognitive awareness, while the test was used to assess their reading comprehension of narrative texts. Pearson Product Moment and regression analyses were conducted to find out the correlation between the two variables. Results of this study show a significant correlation between metacognitive awareness and students' reading comprehension of narrative texts with $\mathrm{r} 0.786>\mathrm{r}$ table 3.961. This research could have implications for the English teacher, students, and next researchers.
\end{abstract}

Key Words: metacognitive awareness; reading comprehension; narrative text

\section{ABSTRAK}

Tujuan dari penelitian ini adalah untuk mendeskripsikan hubungan antara kesadaran metakognitif siswa dengan pemahaman bacaan mereka dalam teks naratif. Penelitian korelasional digunakan dalam penelitian ini. Sampel penelitian ini adalah siswa kelas XI IPS 3 SMAN 3 Bone. Mereka dipilih dengan menggunakan cluster random sampling yang terdiri dari 25 siswa. Peneliti menggunakan angket dan tes untuk mengumpulkan data dari sampel. Angket digunakan untuk mengetahui metakognitif siswa dan tes digunakan untuk mengetahui pemahaman bacaan siswa dalam teks naratif. Product Moment Pearson dan analisis regresi digunakan untuk mengetahui korelasi antara dua variabel. Hasil penelitian menunjukkan bahwa terdapat hubungan yang signifikan antara kesadaran metakognitif dengan kemampuan membaca siswa dalam teks naratif dengan r 0,786> r tabel 3,961. Penelitian ini dapat berimplikasi pada guru bahasa Inggris, siswa, dan peneliti selanjutnya.

Kata Kunci: Kesadaran metakognitif; pemahaman membaca; teks naratif

How to Cite: Rosnaeni, Dj. M. Zuhri , Nur, H. (2020). Students' Metacognitive Awareness and Reading Comprehension of Narrative Texts. IJEE (Indonesian Journal of English Education), 7(1), 74-86. doi:10.15408/ijee.v7i1. 17027

"Corresponding author

IJEE (Indonesian Journal of English Education), 7 (1), 2020, 63-71

P-ISSN: 2356-1777, E-ISSN: 2443-0390 | DOI: http://doi.org/10.15408/ijee.v7i1.17027

This is an open access article under CC-BY-SA license (https://creativecommons.org/licenses/by-sa/4.0/) 


\section{INTRODUCTION}

Reading is a language competency that has an essential role. The students' ability in reading determines student achievement in the teaching-learning process in school. In acquiring knowledge, the fact is that most of the knowledge is in written form, so it requires students to read. Therefore, in teaching, reading learning has a strategic position.

Reading skills are essential in life, but many students have difficulties in reading subject. When there is an obligation to read the text, there will be various student responses, including indifference, lack of seriousness, ignorance, and even mistakes in learning processes and outcomes.

For example, the material on a narrative text in practice has not been applied maximally. It can be seen from the learning outcomes. Based on the writer observations with one of the English teacher in SMA 3 Bone, there were some problems that researcher found, such as difficulties in understanding the text, the difficulty to find out the main idea, lack of vocabulary, the problem of finding the generic structure and making conclusions and still confused in doing the reading task.
The low learning outcomes of these students indicate a poor understanding of reading. During this time, the approach and method used are also insufficient to support students' reading comprehension. As a facilitator in learning, even the teacher often ignores the cognitive and mental processes that occur within the student.

In the process of a reading lesson, the teachers' role is excellent in providing understanding to learners. According to Korabiak, Mete, and Moursund (2004) assumed that the teachers teach the students in improving the phonological and phonics base, integrating the structure, and reading for comprehension. On the other hand, Harvey (2012) also said that one of the most critical skills is reading comprehension.

Reading comprehension involves the readers to know and understand what they are reading. Without understanding the text that has been read, they have fallen short of reading. Knowing and understanding what is being read is instrumental in comprehensive reading.

Reading comprehension, according to van de Broek and Espin (2012), is the complex interaction between automatic and strategic cognitive processes facilitating the reader in creating a mental representation of the text. 
Students will be able to make mistakes in learning, both in-process and learning outcomes. It is related to the non-achievement of goals targeted students; students' attitudes will differ. However, students who have plans and try to manage the process they do will try to reflect so that errors will be smaller in the next task.

Students' learning success can be achieved if students are consciously able to control their cognitive processes and lead to improving their metacognitive knowledge. Cubukçu (2008) assumed that metacognition concerns knowledge, awareness, and control of learning. According to Wilson and Clarke (2004) as cited in Akturk and Sahin (2011), knowledge and awareness have one of their thinking processes and strategies and the capacity of evaluating and regulating one's thought processes.

Metacognitive activity happens when students consciously manage and adjust their thinking strategies when solving problems and thinking about a goal. When students feel conscious of the goals and techniques, they will implement to achieve specific goals, the students will try to manage themselves, knowledge, and experience to accomplish that goal.

According to Chauhan and Singh (2014), metacognitive is the process of linking new information to existing knowledge, creatively selecting thinking strategies, and planning, monitoring, and evaluating thought processes.

The students who lack metacognitive and control of reading strategies often have difficulties coping with academic reading such as textbook because metacognitive ability can make students skilled at reading comprehension.

According to Mokhtari and Sheorey (2002), the development of students' metacognitive awareness can be trained to choose the best strategy in selecting, remembering, re-recognizing, organizing the information it captures and solving problems related to reading passages. The awareness of metacognitive reading strategy affects learners' comprehension as it controls the ways learners interact with the context and their effective use of strategies in their reading comprehension.

The aforementioned statement is supported by Nofyan's (2017) study which found that there is a strong association between metacognitive reading technique, mastery of vocabulary, and student reading awareness of MTsN Surakarta 1 eighth grade students. 
Based on the above explanation, the researchers formulate the problem statement: Do the students of SMAN 3 Bone have any vital connection between the metacognitive knowledge of the students and their reading understanding in the narrative text?

From the above issue, this research aims to identify the relationship between students' metacognitive knowledge and their understanding of reading.

\section{Metacognitive Awareness}

According to Baker and Brown (1980), metacognition deals with "meta" meaning beyond, and "cognition" meaning mental actions or process of achieving knowledge and understanding through experience, thought and the senses. The definition of metacognition itself refers to how someone aims their cognition dealing with strategy and previous knowledge. Additionally, metacognition is the awareness of a person to manage and control their mental cognition process.

Costa (1984) explains metacognition as the ability to understand what someone knows and what someone does not know, to be aware of the strategies and mental operations while solving the problems, to assess and to meditate on our intellectual products. Metacognitive awareness is an individual's knowledge of their metacognitive strategies and metacognitive knowledge.

According to Wilson and Clarke (2004) as cited in Akturk and Sahin (2011), metacognition is the knowledge and awareness that one has of their thought processes and strategies and the ability to evaluate and regulate their thought processes. As applied in reading, this metacognitive strategy requires the goal of reading, planning how the text will be read, and taking actions when something goes wrong if understanding is not achieved.

\section{Reading Comprehension}

Snow (2002) defined reading comprehension as the process of extracting and constructing meaning through constant interactions and engagements with written language. It is supported by Klingner, Vaughn, and Boardman (2015) who state that reading comprehension is the process of constructing the meaning by coordinating several complex processes that include word reading, word, and world knowledge, and fluency.

Therefore, the competence of comprehending the text depends on the readers' skill to interpret or construct what they read. This is in line with Lapp and Fisher (2011) who say that skilled readers are those who actively 
and constantly construct meaning as they read; they are self-motivated and self-directed; and they monitor their understanding by questioning, reviewing, revising, and rereading to enhance their overall comprehension.

From the above explanation, it can be said that reading comprehension is an interactive process among text, readers, and strategies. Thus, the interactive process includes utilizing, understanding and evaluating the critical message that the author tries to convey. Continuously, readers intertwine all that information with their knowledge background to extract the meaning of the written material.

\section{Narrative Text}

According Utami (2017), narrative is a type of text that tells a story and, in doing so, entertains or informs the reader or listener. The narrative is a text that describes a story using a sequence of events in which each genre has its social goal. Gerot and Wignell (1995) argue that the narrative's social function is to entertain, amuse and deal with the real-life experience in various ways.

According to Rahmawati (2010), a narrative is a form of a text intended to retell action or past event to narrate and resolve the problems, to entertain or amuse the readers, and sometimes to offer morality. It typically has a variety of recurring occurrences and an issue that the characters need to solve.

The correlation between metacognitive awareness and reading comprehension

Metacognitive awareness and reading comprehension have a sustainable relationship. Metacognitive techniques are essential for efficient reading as with any form of learning and are at work at both the micro and macro processing stages.

Pressley (2002) stresses that the use of metacognitive techniques enumerates professional metacognitive readers' features. He also describes the metacognitively advanced reader is excellent at asking questions while engaged in reading, visualizing what is being read, and understanding how to summarize the text. Accordingly, a reader knows that he can come across some confusing sections in the text. Thus, he deliberately adopts some basic methods to deal with the uncertainty.

It means that metacognition plays a vital role in reading. Throughout the reading, metacognitive processing can be expressed throughout strategies, such as the procedural, the purposeful, the effortful, the willful, the essential, and the facilitative. 


\section{METHOD}

This research employed
quantitative research with a
correlational design to assess
metacognitive awareness and reading
comprehension relationship in
narrative text.

This research applied two variables, the independent and dependent variable. The independent variable was metacognitive awareness symbolized as " $\mathrm{X}$ ", and the dependent variable was reading comprehension in narrative text symbolized as "Y".

In this research, the writer used a cluster random sampling to select the participants. The class of XI IPS 3, which consists of 25 students, has been chosen randomly to be the sample for this study.

A questionnaire and test were used as the research instruments of this study. A questionnaire, which consists of 52 Items, was used to collect data about students' metacognitive awareness. This questionnaire includes several subscales assessing cognition (declarative knowledge, procedural knowledge, conditional knowledge) and regulation of knowledge (planning, information management strategies, monitoring, debugging strategies and evaluation). Then, the researcher used the Likert Scale. According to Croasmun and Ostrom (2011), Likert scales provide a range of responses to a statement or series of statements. Usually, five response categories range from 5 = strongly true to 1 = strongly false. The questionnaires given to the students were to obtain their metacognitive awareness. At the same time, tests are assessment instruments that pose problems for students to solve. Then, to get the students' reading comprehension, the researchers used multiple-choice in a reading comprehension test. There were 20 questions of multiple choices in narrative text.

In data analysis, the researchers analyzed two data sets. They were the results of the questionnaire and test. More specifically, the following steps are explored below.

\section{Analysis of students' metacognitive awareness}

The questionnaire determining the students' metacognitive awareness in reading was checked manually. The samples were asked to checklist the statements based on how well the statements describe them. The scoring of the Likert scale is described in the table 1. 
Table 1. Likert Scale for Questionnaires

\begin{tabular}{ll}
\hline Category & Score \\
\hline Strongly True & 5 \\
True & 4 \\
Neutral & 3 \\
False & 2 \\
Strongly False & 1 \\
\hline
\end{tabular}

The researcher categorized the interval of metacognitive awareness. According to Sugiyono (2005), a considerable interval from the highest score minus the lowest score is obtained and then divided by the number of questions.

The interval of metacognitive awareness was calculated by the formula below:

$$
\mathrm{I}=\longdiv { \frac { H S - L S } { K } }
$$

Where:

I = Interval

HS $=$ The highest score

LS $=$ The lowest score

$\mathrm{K}=$ Total number of categories

Therefore, students' metacognitive awareness classified as table 2 .
Table 2. The Categories of Metacognitive Awareness

\begin{tabular}{ll}
\hline Score & Categories \\
\hline $220-260$ & Very Good \\
$178-219$ & Good \\
$136-177$ & Fair \\
$94-135$ & Poor \\
$52-93$ & Very poor \\
\hline
\end{tabular}

\section{Analysis of reading comprehension}

The narrative text data for reading comprehension is graded by the formula below:

$$
\mathrm{S}=\overline{F / N} \times 100 \%
$$

Where:

$$
\begin{aligned}
& S=\text { Individual Score } \\
& F=\text { Number of Correct Answer } \\
& N=\text { Number of Item }
\end{aligned}
$$

Table 3. The Categories of Reading Comprehension

\begin{tabular}{ll}
\hline Score & Category \\
\hline $93-100$ & Excellent \\
$84-92$ & Very Good \\
$75-83$ & Good \\
$66-74$ & Average \\
$56-65$ & Poor \\
$<55$ & Very Poor
\end{tabular}

(Source: Staff Administration of SMA 3 Bone 2018) 
Analysis of the correlation between students metacognitive awareness and reading comprehension

The relationship in the narrative text between students' metacognitive knowledge and their understanding of reading was analyzed using statistical calculation through SPSS.

Then, based on the Sugioyo (2005), he divided the interpretation of the correlation coefficient values in the following table 4 .

Table 4. Interpretation of Correlational Coefficient

\begin{tabular}{ll}
\hline $\begin{array}{l}\text { Coefficient } \\
\text { Interval }\end{array}$ & Level of correlation \\
\hline $0,00-0,199$ & The relations are very low \\
$0,20-0,399$ & The relations are low \\
$0,40-0,599$ & The relations are medium \\
$0,60-0,799$ & The relations are strong \\
$0,80-1,000$ & The relations are very strong \\
\hline
\end{tabular}

\section{FINDINGS AND DISCUSSION}

\section{Findings}

\section{The result of student's metacognitive awareness}

The total active students in the eleventh grade, especially in the XI IPS 3 of SMAN 3 Bone class, were 25 students. The 52 items of Metacognitive Awareness Inventory (MAI) were used to analyze the students' metacognitive consciousness. The data was taken from the questionnaire will answer the first research question about the student's metacognitive awareness. The researchers analyzed the data by SPSS 25.00 versions. As for the data of students' metacognitive awareness result can be explained as follows table 5.

Table 5. Distribution of Students' Metacognitive Awareness

\begin{tabular}{llll}
\hline Score & $\begin{array}{l}\text { Freq. } \\
\text { (F) }\end{array}$ & $\begin{array}{l}\text { Percentage } \\
(\mathbf{\%})\end{array}$ & Categories \\
\hline $220-260$ & 3 & $12 \%$ & Very Good \\
$178-219$ & 13 & $52 \%$ & Good \\
$136-177$ & 9 & $36 \%$ & Fair \\
$94-135$ & 0 & 0 & Poor \\
$52-93$ & 0 & 0 & Very poor \\
\hline Total & 25 & $100 \%$ & \\
\hline
\end{tabular}

Based on the table 5, there are five classes of interval. At the interval score 52-93, there are 0 students. At the interval 94-135, there are 0 students. At the interval 136-177, there are nine students. At the interval 178-219, there are 13 students, and at the interval 220260 , there are three students. It can be seen that the highest frequency is 13 in $52 \%$, and the lowest frequency is 0 in $0 \%$.

\section{The Result of Students' Reading Comprehension in Narrative Text}

The outcome of reading comprehension was calculated by giving the students a reading comprehension test, and the total number of questions for each category 
was 20 items. The effect of students reading comprehension in the narrative text was represented in the table 6.

Table 6. Distributive Frequency of Students' Reading Comprehension in Narrative Text Category

\begin{tabular}{lccc}
\hline Score & $\begin{array}{c}\text { Frequency } \\
(\mathrm{F})\end{array}$ & $\begin{array}{c}\text { Percentage } \\
(\%)\end{array}$ & Category \\
\hline $93-100$ & 1 & $4 \%$ & Excellent \\
$84-92$ & 6 & $24 \%$ & Very Good \\
$75-83$ & 7 & $28 \%$ & Good \\
$66-74$ & 6 & $24 \%$ & Average \\
$56-65$ & 0 & 0 & Poor \\
$<55$ & 5 & $20 \%$ & Very Poor \\
\hline Total & 25 & $100 \%$ & \\
\hline
\end{tabular}

The table 6, presented the frequency of students' reading comprehension scores. The interval classes are 6 . At the interval score $<55$ there are six students. At 56-65 there are 0 students. At the interval 66-74, there are five students. At the interval 75-83, there are seven students. At the interval 84-92, there are six students, and at the interval 93-100, there is one student. The highest frequency is 7 in $28 \%$, and the lowest frequency is 0 in $4 \%$. In short, most students had a good score in their reading comprehension skills.

\section{The Correlation between Students' Metacognitive Understanding and Their Reading Comprehension in Narrative Text}

This section discusses the first research issue by evaluating the MAI questionnaire's descriptive statistics and reading comprehension findings. Based on the Pearson Product Moment Correlation Coefficient, the result showed a strong correlation between metacognitive knowledge and reading understanding in narrative text.

Table 7. The Result of Correlation Analysis between Metacognitive Awareness and Reading Comprehension in Narrative Text

\begin{tabular}{|c|c|c|c|}
\hline & & $\begin{array}{l}\text { Meta- } \\
\text { cognitive }\end{array}$ & Reading \\
\hline \multirow[t]{3}{*}{$\begin{array}{l}\text { Meta- } \\
\text { cognitive }\end{array}$} & $\begin{array}{l}\text { Pearson } \\
\text { Correlation }\end{array}$ & 1 & $.759^{* *}$ \\
\hline & $\begin{array}{l}\text { Sig. (2- } \\
\text { tailed) }\end{array}$ & & .000 \\
\hline & $\mathrm{N}$ & 25 & 25 \\
\hline \multirow[t]{3}{*}{ Reading } & $\begin{array}{l}\text { Pearson } \\
\text { Correlation }\end{array}$ & $.759^{4 *}$ & 1 \\
\hline & $\begin{array}{l}\text { Sig. (2- } \\
\text { tailed) }\end{array}$ & .000 & \\
\hline & $\mathrm{N}$ & 25 & 25 \\
\hline
\end{tabular}

Based on the analysis, the correlation coefficient for metacognitive knowledge and reading comprehension is $0.759 \geq 0.3961$. It implies that there is a clear connection between students' metacognitive understanding and reading comprehension at Sig.000. Since the significance is less than 0.05 , this means that the first hypothesis is accepted. 


\section{Discussion}

First, from the results of data collection through questionnaire instruments for knowing the level of metacognitive awareness of secondgrade students of SMAN 3 Bone, then after being analyzed using descriptive statistics, it can be stated that of the 25 students who were used as research samples, the highest scores were obtained amounting to 240, and the lowest value was 152 . The average score (mean) was 190.60, and the standard deviation was 24.587. When viewed from these data, the level of metacognitive awareness of students was in a suitable category. It can be seen from the average value of 190.60 in the interval 178-219, with a percentage of $58.4 \%$. Thus, it can be concluded that metacognition awareness was in a suitable category.

It was found that the students were able to regulate their metacognitive. A right level of metacognitive awareness is related to students' ability to plan, monitor, and evaluate thinking processes. As a result, if students already have an interest, desire to learn, participate in understanding the material, and be responsible for their learning, they become aware of their metacognitive. Good metacognitive awareness will learn better than those without metacognitive awareness.
Then, in this research, the researcher gave a reading test to collect students' reading comprehension data. From 25 students as the research sample, the highest value was 95 , the lowest value was 20 , the mean score was 74.40 , and the standard deviation was 14.136. When viewed from these data, the students' reading comprehension was in a low category. It is shown that the data was in the interval 66-74 with a percentage of $24 \%$, it can be assumed that students' reading understanding was in the average category. It means that the students should enhance their comprehension of reading to be better than before.

The result of this study was also strengthened by Nugroho (2017). In his study, he found a strong association between metacognitive reading techniques, vocabulary mastery, and student's understanding of reading. He said that enhancing students' metacognitive reading approach would improve their reading comprehension.

The need for a metacognitive reading technique is essential for reading comprehension. The higher students' metacognitive reading strategies are, the higher their reading comprehension is.

On the other hand, based on the Pearson product-moment correlations, it was found that there was a strong 
and robust correlation between student metacognitive knowledge and reading comprehension in narrative text.

It was found that $r$-obtained $0.759 \geq$ 0, 3961, and p-output (sig. 2- tailed) $0000 \leq 0,05$ It means there was a correlation between metacognitive knowledge and reading comprehension. Students were aware of reading comprehension in such a way that they used reading techniques to get a positive outcome in their reading comprehension.

This finding is in line with a previous study by Urfa (2017) which indicates that good readers use metacognitive reading strategy is to think about and have control over their reading. It means reasonable control of students' metacognitive reading strategy use will be better to help them easy to understand the text.

In reality, metacognitive helps students to have a strategy and specific goals. They prepare how to read well to find the text's primary meaning, the essential purposes of the text, and try to understand the text easily. Students often have specific goals that can decide any reading aspect, the main idea, supporting detail, reference, vocabulary, cause, and conclusion.

Also, most students' metacognitive knowledge was categorized at an acceptable level, and the students' reading comprehension was also categorized at an average level. It means that students are only aware of the strategies, although they do not follow the procedure while reading.

Students who typically use reading strategies may be better in reading comprehension, and students who seldom or never use reading strategies have been weak in reading comprehension. In this analysis, the correlation coefficient was defined as a significant correlation.

\section{CONCLUSION AND SUGGESTION}

Based on the findings, the researcher concluded that there was a significant correlation between metacognitive knowledge and student reading comprehension in the narrative text at the eleventh-grade students' of SMAN 3 Bone since the correlation coefficient (0.759) was higher than $r$ table (0.3961), and p (.000) was lower than (.05) The category of correlation was strong.

The present result also has consequences for students that the more excellent knowledge of metacognitive reading, the greater their understanding of reading will be.

Based on the explanation above, the researcher acknowledges that this 
study's outcome is still far from perfect. There are also many drawbacks in dealing with the theory or the other due to the researcher's limited knowledge. The researcher also acknowledges that this research paper only makes a minor contribution to teaching reading. The other researchers are expected to expand this study with their content and use different relevant approaches for students to make new contributions to the field of English education.

\section{REFERENCES}

Akturk, A. O., \& Sahin, I. (2011). Literature review on metacognition and its measurement. Procedia-Social and Behavioral Sciences, 15, 3731-3736.

Baker, L., \& Brown, A. L. (1980). Metacognitive skills and reading. Technical Report No. 188.

Chauhan, A., \& Singh, N. (2014). Metacognition: A conceptual framework. International Journal of Education and Psychological Research (IJEPR), 3(3), 21-22.

Costa, A. L. (1984). Mediating the metacognitive. Educational Leadership, 42(3), 57-62

Croasmun, J. T., \& Ostrom, L. (2011). Using Likert-Type Scales in the Social Sciences. Journal of Adult Education, 40(1), 19-22.

Cubukçu, F. (2008). Enhancing vocabulary development and reading comprehension through metacognitive strategies. Issues in Educational Research, 18(1), 1-11.
Gerot, L., \& Wignell, P. (1995). Making Sense of Functional Grammar Sydney: Antipodean Educational Enterpress.

Harvey, M. (2012). Reading comprehension: Strategies for elementary and secondary school students. Lynchburg College Johnson.

Klingner, J. K., Vaughn, S., \& Boardman, A. (2015). Teaching reading comprehension to students with learning difficulties. New York: Guilford Publications.

Korabiak, K., Mete, N., \& D Moursund, D. (2004). ICT in the discipline of Reading. Retrieved from https:// scholar.google.com/scholar? cluster $=4950212016643272651 \& \mathrm{hl}=\mathrm{en}$ \&as_sdt $=0,5$

Lapp, D., \& Fisher, D. (Eds.). (2011). Handbook of research on teaching the English language arts: Co-sponsored by the International Reading Association and the National Council of Teachers of English. London: Routledge.

Mokhtari, K., \& Sheorey, R. (2002). Measuring ESL students' awareness of reading strategies. Journal of developmental education, 25(3), 2-11.

Nofyan, A. N. (2017). The correlation between metacognitive reading strategy, vocabulary mastery and students' reading comprehension the eighth-grade students of MTsN Surakarta 1 In The Academic Year Of 2016/2017 (Unpublished, undergraduate thesis). IAIN Surakarta, Sukoharjo.

Pressley, M. (2002). Metacognition and selfregulated comprehension. What research has to say about reading instruction, 3, 291-309. 
Rahmawati, F. (2010). Using Picture Stories to Improve the Student's Reading Comprehension (Unpublished undergraduate thesis). Universitas Sebelas Maret Surakarta, Surakarta.

Snow, C. (2002). Reading for understanding: Toward a research and development program in reading comprehension. Santa Monica: RAND Education.

Sugiyono, S. (2016) Metode penelitian pendidikan pendekatan kuantitatif, kualitatif, dan RED. Bandung: Alfabeta.

Urfa, S. (2017). Multiple correlations between students' vocabulary mastery and metacognitive reading strategy toward reading comprehension at the tenth-grade students of SMA Muhammadiyah 1 Palangka Raya. (Unpublished Doctoral thesis). IAIN Palangkaraya, Palangkaraya.
Utami, I. P. (2017). The effectiveness of prequestioning technique to teach reading comprehension of narrative text. Journal of English Language Teaching, 6(1), 59-68.

van den Broek, P., \& Espin, C. A. (2012). Connecting cognitive theory and assessment: Measuring individual differences in reading comprehension. School Psychology Review, 41(3), 315-325.

Wilson, J. \& Clarke D. 2004. Towards the Modelling of Mathematical Metacognition. Mathematics Education Research Journal., 16(2), 25-48. 